\title{
The Marginalization of Africa in World Trade
}

$\mathrm{I}^{\mathrm{n}}$

$\mathrm{n}$ recent years, trade in Africa has assumed greater importance as a means of alleviat-

ing poverty, especially since the initiation of the Doha Round for development. At the same time, skepticism regarding the effectiveness of foreign aid has grown (Easterly 2006). Trade and aid have often been viewed as interchangeable, but "aid for trade" has recently gained prominence, with the result that the two factors are more often treated as complementary. Proponents of "aid for trade" argue that the capacity of developing countries to take advantage of any gains in market access through the Doha Round is hampered by a plethora of supply-side bottlenecks and costs, administrative constraints, and poor institutions. Aid for trade, thus, refers to additional aid to tackle trade-related constraints and adjustment costs in developing countries (Evenett 2005). ${ }^{1}$ Views differ as to what this package should entail, but many developing countries are in favor of building supplycapacity and trade-related infrastructure (IATP 2006).
Saswati Bora

Antoine Bouët

Devesh Roy
In debates about globalization, Africa's ability to take advantage of trading opportunities has always been under contention. Data indicate that the continent's share of world exports has declined sharply, from about 5.5 percent in 1975 to about 2.5 percent in 2002 (Figure 1). At face value, this declining share points to the increased marginalization of Africa in world trade, but the observed pattern of trade need not be inconsistent with predicted trade, which is dependent on income levels and trading costs between countries, among other factors. Evidence from existing literature on the trading status of Africa is mixed, based on varying timeframes, methodologies, and regions of focus (for example, comparisons among developing countries or between industrialized and developing countries).

Researchers like Sachs and Warner (1997) assert that Africa has been left out of the process of globalization, while the World Bank (2000) states that losses in world trade have cost Africa almost US\$70 billion a year, reflecting lack of product diversification and shrinking market shares for traditional goods. Subramanian and Tamirisa (2001) also find evidence for the marginalization of Africa in world exports. Separating the continent into two distinct regions, they find that Central and West Africa has exhibited increasingly low trade performance over time, whereas East and Southern Africa has shown average performance with indications that it also may not be keeping pace with global integration.

In contrast to the studies cited above, a number of other studies argue that Africa's trade flows have been consistent with predicted trade, meaning that the continent has successfully utilized trading opportunities based on changes in the factors that determine trade levels. A pioneering study by Foroutan and Pritchett (1993) argues that there is no evidence to suggest that trade flows within Sub-Saharan Africa were differentially low, either as a result of poor policy choices or weak infrastructure. The authors observe that trade flows tallied with predicted trade levels and that low levels of trade could be explained by low levels of gross domestic product (GDP).

According to Rodrik (1998), Africa participates in international trade as much as can be expected according to international benchmarks for trade volume derived from a country's income level, size, and geographic location. Coe and Hoffmaister (1998) support Rodrik's results, estimating a gravity model of bilateral trade between developing and industrialized countries. Their results indicate that in the early $1990 \mathrm{~s}$ the trade performance of Africa was in fact normal compared with developing countries in other regions.

${ }^{1}$ Aid for trade was officially put on the World Trade Organization (WTO) agenda at the 6th Ministerial Conference held in Hong Kong in December 2005, and the proposal that WTO governments develop an aid for trade package arose in the context of Doha Round negotiations. 
Figure I-Africa's share of world exports

(goods and services), 1970-2002

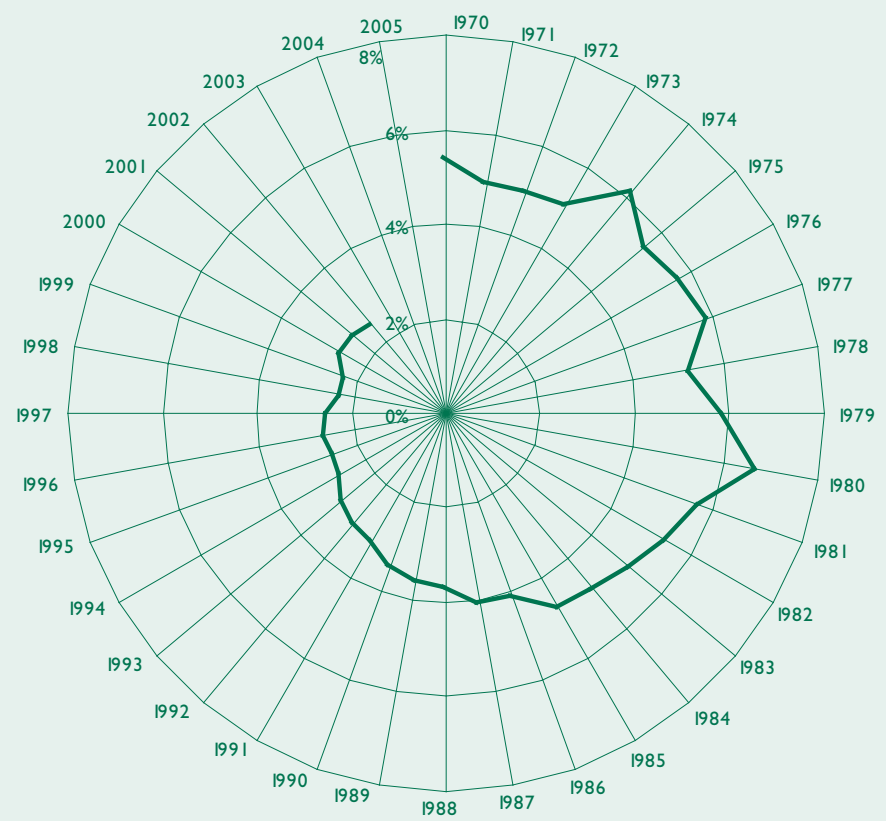

Source: World Bank 2006.

These authors do, however, point to a declining trend in the performance of North-South trade in Africa over the past 25 years, which markedly contrasts with the increasing trend in Latin America and the broadly stable pattern in Asia. Subramanian and Tamirisa (2001) note that Coe and Hoffmaister (1998) do not control for a key variable in their analysis - the preferential trading arrangement between Africa and the European Union under the Lomé Convention.

Against this background, in this brief we revisit the issue of Africa's trade performance using a comprehensive dataset on trade protection, the MAcMap database (Bouët et al. 2007). The highlight of the dataset is that it captures a more extensive set of trade protection measures and allows for country-specific levels of market access. We begin by evaluating the levels of existing market access for Africa and assess whether or not Africa trades less than its predicted level. Further, we quantify the impact of infrastructure on trade using a framework that allows the interaction of infrastructure variables. Importantly, our results show that Africa has good market access at the continent level, second only to Europe, but that access varies widely across countries within Africa. Building on this result, we capture country-specific market access in our empirical analysis, while explaining Africa's trade performance. Notably, the timeframe for the analysis, 2001 and 2004, enables the inclusion of the effect of two large-scale preferential trade arrangements for Africa: the Everything but Arms Initiative and the African Growth and Opportunity Act.

\section{Market Access for Africa}

In the debate over trade versus aid, proponents of the ineffectiveness of aid often argue that Africa's trade prospects can be improved by enhanced market access, mainly via discriminatory preferences vis-à-vis the rest of the world. This begs the question, how good is current market access for Africa relative to the rest of the world? In this section, we assess Africa's access to world markets. Data on average export duties by region, country, and income group are provided in Table 1. Europe has the best access to foreign markets, on average, but African market access is in fact better than that of North and Latin America, Asia, and the Pacific region. There are significant variations within Africa, however, with 21 countries having better access than the world average, and 11 countries incurring export duties of less than 2 percent. Thirty-two countries have market access below the world average, with 13 countries incurring average export duties of more than 10 percent and Malawi facing tariffs of 23.1 percent.

This contrasting picture of countries across Africa with regard to access to foreign markets arises from two different effects. First, the structure of world protection is unequally distributed among sectors and across importers. Countries that are highly specialized in certain agricultural products—such as meat, milk, sugar, or some cereals—are penalized, as are those that export to protectionist countries. This is called a "composition effect." At the same time, however, preferential access decreases average export duties for countries to which it is granted. This second effect is the "true preference margin." If the composition effect is positive, even in the absence of preferences, a country will benefit from a lower tariff rate than the world average. A positive true preference margin implies that the country benefits from a higher preference than the world and vice versa.

For Africa, the true preference margin is negative (Table 2). Hence, on average, African exports are given lower preference compared with the world. Europe benefits from the largest true preference margin due to the European Union. Thus, since African countries enjoy good market access despite a negative true preference margin, the good market access results from the composition effect. The benefit to Africa occurs when it faces a lower average duty than the world does (by 0.3 percent), due to specializations in oil, gas, and mineral products or commodities that are not highly taxed throughout the world. Within Africa, exports from Benin, Malawi, Mauritius, Swaziland, and Togo are penalized due to specializations in highly protected products, while preferences only partially compensate. In contrast, Chad, the Democratic Republic of Congo, and Libya each have a very strong and positive composition effect. This phenomenon reinforces the importance of accounting for country specificity in capturing the effect of market access for Africa.

\section{The Impact of Free Access to Africa}

With a negative true preference margin, Africa could experience significant growth in market access because of trade preferences, though the above results also show the possibility of significant 
variation across countries. Generating simulations from the MIRAGE model $^{2}$ using the MAcMap database, Berisha-Krasniqi et al. (2007) analyze to what degree African export levels could increase with improved market access. The three scenarios modeled involve the impact in 2015 of providing 55 African countries with free trade access (a) in the United States; (b) in OECD countries excluding Korea and Mexico; and (c) in OECD countries plus Brazil, China, and India.

Duty-free/quota-free (DFQF) access has no impact on exports for countries that already have good access (Table 3). Hence three African countries-Botswana, with good access due to trade in diamonds, copper, and nickel; Nigeria, an oil exporter; and Zambia, a copper exporter-barely experience any boost in exports as a result of DFQF access. Other countries, however, do experience a significant positive effect from DFQF access: exports of products like sugar (from Madagascar, Mozambique, Malawi, Tanzania and Uganda), milk and dairy (from Mozambique and Uganda), textiles (from Madagascar, Malawi, and Uganda), and apparel (from Madagascar, Malawi, Mozambique, and Tanzania) increase significantly. ${ }^{3}$

\section{Africa: The Role of Market Access and Domestic Factors in Marginalization}

The next question is whether Africa's trade flows should in fact be higher given the current level of market access, or whether they would remain below predicted levels even if market access were enhanced.

To answer this question, we use a gravity model to analyze the patterns of bilateral trade (that is, trade between two countries), which is formally specified in the model as a function of the trading costs and GDP of both the exporting and the importing countries. ${ }^{4}$ In principle, it is not only the absolute trading costs between two countries that are important, but also the costs of trading with the rest of world,
Table I -Tariff protection applied to exports, 2004 (percent)

\begin{tabular}{lcccc} 
& \multicolumn{5}{c}{ Exports } \\
\cline { 2 - 5 } Region/country & Global & Agricultural & Industrial & $\begin{array}{c}\text { Primary } \\
\text { nonagricultural }\end{array}$ \\
\hline Africa & 4.2 & 15.2 & 3.9 & 1.6 \\
Angola & 1.5 & 6.4 & 0.9 & 1.5 \\
Democratic Republic of Congo & 1.2 & 17.3 & 0.7 & 1.1 \\
$\quad$ Lesotho & 1.3 & 9.2 & 1.3 & 2.5 \\
$\quad$ Malawi & 23.1 & 27.4 & 8.5 & 6.1 \\
Asia & 5.1 & 19.3 & 4.9 & 1.6 \\
Europe & 3.6 & 12.1 & 2.9 & 1.2 \\
Pacific region & 10.6 & 32.1 & 4.3 & 2.5 \\
North and Latin America & 5.3 & 18.5 & 3.7 & 1.2 \\
Least-developed countries & 4.7 & 15.3 & 4.3 & 2.0 \\
Middle-income countries & 5.1 & 20.0 & 4.6 & 1.5 \\
OECD countries & 4.1 & 14.0 & 3.3 & 1.3 \\
World & 4.5 & 16.0 & 3.7 & 1.5 \\
\hline
\end{tabular}

Source: Bouët et al. 2007.

Note: OECD indicates Organisation for Economic Co-operation and Development.

\section{Table 2 -Apparent margin and its decomposition for sample African} countries, world regions, and economic groups, 2004

\begin{tabular}{lcccc} 
Region/country & $\begin{array}{c}\text { Applied } \\
\text { duty }\end{array}$ & $\begin{array}{c}\text { Apparent } \\
\text { margin }\end{array}$ & $\begin{array}{c}\text { Composition } \\
\text { effect }\end{array}$ & $\begin{array}{c}\text { True preference } \\
\text { margin }\end{array}$ \\
\hline Africa & 4.2 & 0.3 & 0.6 & -0.3 \\
$\quad$ Chad & 1.3 & 3.3 & 4.0 & -0.8 \\
$\quad$ Democratic Republic of Congo & 1.2 & 3.3 & 4.5 & -1.2 \\
$\quad$ Malawi & 23.1 & -18.6 & -23.1 & 4.5 \\
$\quad$ Togo & 14.9 & -10.4 & -10.8 & 0.5 \\
Asia & 5.1 & -0.6 & 0.5 & -1.1 \\
Europe & 3.6 & 0.9 & 0.1 & 0.8 \\
Pacific region & 10.6 & -6.0 & -5.3 & -0.7 \\
North and Latin America & 5.3 & -0.8 & -0.8 & 0.1 \\
Least-developed countries & 4.7 & -0.1 & -1.2 & 1.1 \\
Middle-income countries & 5.1 & -0.6 & 0.1 & -0.7 \\
OECD countries & 4.1 & 0.4 & 0.0 & 0.4 \\
World & 4.5 & & & \\
\hline
\end{tabular}

Source: Bouët et al. 2007.

Note: OECD indicates Organisation for Economic Co-operation and Development.

so both are included in our regressions. The variable of interest is the dummy variable capturing Africa as the exporter. Table 4 presents the results of the simplest Ordinary Least Squares (OLS) regressions. ${ }^{5}$

Globally, if infrastructure is not taken into account (Columns 1 and 3 of Table 4), the coefficient of the African

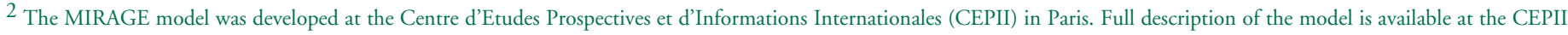
website (www.cepii.fr).

3 Critics have raised concerns that OECD-country access to African markets will crowd out low-income non-African country exports. Our findings, however, indicate that this

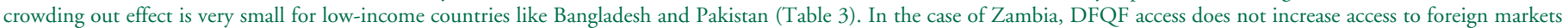

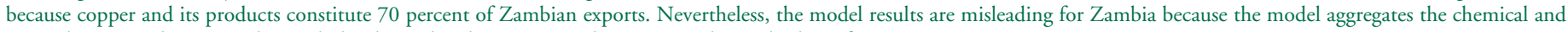
mineral sector and erroneously concludes that redistribution occurs between Zambia and other African countries.

4 Trading costs are captured by variables such as transport costs (proxied by bilateral distance) and trade barriers (such as bilateral tariffs between the two countries).

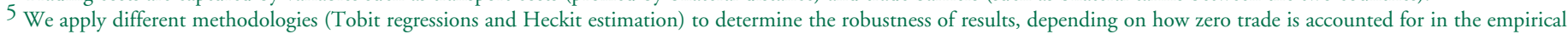
specifications. For brevity, the results are not presented here; they are nevertheless qualitatively robust to different specifications.
} 
Table 3 -Projected impact of duty free/quota free access on exports from African and other countries, 2015 (percentage volume)

\begin{tabular}{|c|c|c|c|}
\hline Country & United States & $\begin{array}{c}\text { OECD } \\
\text { countries }\end{array}$ & $\begin{array}{c}\text { OECD and } \\
\text { other countries }\end{array}$ \\
\hline Bangladesh & -0.3 & -0.3 & -0.1 \\
\hline Botswana & 0.0 & 1.7 & -1.0 \\
\hline Madagascar & 9.8 & 15.5 & 44.5 \\
\hline Malawi & 2.7 & 7.8 & 7.1 \\
\hline Mauritius & 3.1 & 13.0 & 26.0 \\
\hline Mozambique & 0.3 & 1.4 & 5.5 \\
\hline Nigeria & 0.0 & 0.1 & 0.6 \\
\hline Pakistan & -0.1 & -0.5 & -0.2 \\
\hline South Africa & 0.1 & 3.7 & 15.0 \\
\hline Tanzania & 0.1 & 2.0 & 8.5 \\
\hline Uganda & 0.1 & 2.3 & 3.7 \\
\hline Zambia & -0.1 & -0.9 & -2.6 \\
\hline Zimbabwe & 0.3 & 3.6 & 5.8 \\
\hline
\end{tabular}

Source: MIRAGE model projections, 2007.

Notes: United States indicates a scenario whereby the United States gives duty free/quota free (DFQF) access to 55 African countries; Organisation for Economic Co-operation and Development (OECD) countries indicates a scenario whereby OECD countries, with the exception of Korea and Mexico, give DFQF access to 55 African countries; and OECD and other countries indicates a scenario whereby OECD countries, together with Brazil, China, and India, give DFQF access to 55 African countries.

dummy is significantly negative, indicating that GDP, geographic distance, and access to foreign markets do not fully explain Africa's low trade performance. In the same sample, however, if trade-related infrastructure is included (that is, air and road transportation and communications infrastructure), the significance of the African dummy is removed. 6 In our analysis, Africa's trade performance is not low in the context of other low-income countries. Hence, factors associated with positive trade impacts in low-income countries—such as traderelated infrastructure-come to the fore as likely explanations for Africa's trade marginalization.

\section{The Impact of Infrastructure on Trade}

Having established that infrastructure is a potential factor in Africa's lower than expected trade flows, we employ a semi-parametric specification of the gravity model that enables all possible interactions across types of infrastructure when estimating their impact on trade. We consider two infrastructure variables at a time: road density and cell phone density. Figure 2 presents the impact of small increases in cell phone density on trade flows in African countries in 2001 and 2004. The impact of cell phone density in all countries increases drastically between 2001 and 2004. The marginal impact on trade is much higher in 2004. This is possibly due to network effects, implying that the same percentage increase in cell phone density is much more productive in 2004, given a significantly higher base number of cell phone users.

In a counterfactual exercise, all countries in the sample are set to have the same level of road density (Figure 3). The two data lines present the marginal impact of cell phones when all countries have a road density equal to the highest 50 percent of the sample and 90 percent of the sample, respectively. When the common level of road density increases, the marginal impact of cell phones also increases. We interpret this as evidence that road and cell phone infrastructure are complementary.

\section{Conclusions and Policy Implications}

The results of our assessment indicate that, on average, Africa's access to foreign markets is good, but significant variations occur across countries. In particular, access by some of the very low-income countries, like Malawi, is comparatively bad. Trade preferences have the potential to improve market access by lowering African export duties. Based on the recipients of African exports (by country) and the types of products exported, Africa's true preference margin is currently negative. This implies that greater market access will benefit African exports, but the effects will vary by country. The evidence does indicate, however, that even if preferences were to enhance export levels, it is possible that African trade would remain below the ideal level, possibly due to low levels of trade-related infrastructure. This implies that interventions to improve both the level and quality of infrastructure could yield high returns, albeit depending on significant complementarities. Consequently, policy interventions that promote piecemeal infrastructure development are likely to yield much lower returns than those stemming from comprehensive infrastructure development strategies.

\footnotetext{
${ }^{6}$ In Tobit and Heckit estimations, the significance of the African dummy is invariably reduced.
} 
Table 4 -Gravity model results for Africa's export status, with and without controlling

for infrastructure, $200 \mathrm{I}$ and 2004

\begin{tabular}{|c|c|c|c|c|}
\hline \multirow[b]{2}{*}{$\begin{array}{l}\text { Log linear specification, } \\
200 \text { I (variable) }\end{array}$} & \multicolumn{2}{|c|}{2001} & \multicolumn{2}{|c|}{2004} \\
\hline & $\begin{array}{l}\text { No accounting for } \\
\text { infrastructure } \\
\text { (I) }\end{array}$ & $\begin{array}{l}\text { Accounting for } \\
\text { infrastructure } \\
\text { (2) }\end{array}$ & $\begin{array}{c}\text { No accounting } \\
\text { for infrastructure } \\
\text { (3) }\end{array}$ & $\begin{array}{c}\text { Accounting for } \\
\text { infrastructure } \\
\text { (4) }\end{array}$ \\
\hline \multirow[t]{2}{*}{ GDP importer } & $0.96 * * * *$ & $0.96 * * *$ & $0.90^{* * * * *}$ & $0.90^{* * * *}$ \\
\hline & $(78.09)$ & $(78.37)$ & $(39.55)$ & $(40.17)$ \\
\hline \multirow[t]{2}{*}{ GDP exporter } & $1.10^{* * 2 * *}$ & $1.08 * * *$ & $1.18^{* * * *}$ & $1.15^{* * * *}$ \\
\hline & $(97.16)$ & $(83.08)$ & $(61.96)$ & $(57.19)$ \\
\hline \multirow[t]{2}{*}{ Bilateral distance } & $-1.49 * * *$ & $-1.49 * 1 * k$ & $-1.49 * k *$ & $-1.49 * * 2 k$ \\
\hline & $(-40.93)$ & $(-40.83)$ & $(-24.72)$ & $(-24.95)$ \\
\hline \multirow[t]{2}{*}{ Distance of exporter from rest of the world } & $0.81^{* * 1 * k}$ & $1.27 * * *$ & $1.29 * * *$ & $2.02 * * *$ \\
\hline & $(6.61)$ & $(8.04)$ & $(6.58)$ & $(8.8 \mathrm{I})$ \\
\hline \multirow[t]{2}{*}{ Distance of importer from rest of the world } & $0.59 * 1 * *$ & $0.58^{* * 2 * k}$ & -0.13 & -0.17 \\
\hline & $(4.75)$ & $(4.68)$ & $(-0.64)$ & $(-0.84)$ \\
\hline \multirow[t]{2}{*}{ Bilateral tariff } & 0.06 & 0.03 & $-0.32^{* * * *}$ & $-0.38^{* * * *}$ \\
\hline & $(1.20)$ & $(0.72)$ & $(-3.50)$ & $(-4.12)$ \\
\hline \multirow[t]{2}{*}{ Relative import protection } & 0.05 & 0.03 & 0.07 & 0.07 \\
\hline & $(1.45)$ & $(1.05)$ & $(1.35)$ & $(1.25)$ \\
\hline \multirow[t]{2}{*}{ Relative export protection } & $-0.12^{* * * *}$ & $-0.1 * *$ & 0.31 **** & 0.36 **** \\
\hline & $(-2.77)$ & $(-2.10)$ & $(4.06)$ & $(4.64)$ \\
\hline \multirow[t]{2}{*}{ Nontariff barriers } & $-0.04 * *$ & $-0.05^{\text {** }}$ & -0.03 & -0.04 \\
\hline & $(-2.14)$ & $(-2.20)$ & $(-0.81)$ & $(-1.14)$ \\
\hline \multirow[t]{2}{*}{ Landlocked exporter } & $-0.11 *$ & -0.09 & $-0.20 * *$ & -0.02 \\
\hline & $(-1.72)$ & $(-1.37)$ & $(-1.97)$ & $(-0.19)$ \\
\hline \multirow[t]{2}{*}{ Landlocked importer } & $-0.5 I^{* * *}$ & $-0.51 * * *$ & $-0.53 * * *$ & $-0.54 * * * *$ \\
\hline & $(-7.88)$ & $(-7.94)$ & $(-4.48)$ & $(-4.59)$ \\
\hline \multirow[t]{2}{*}{ Colonial linkage } & $0.63^{* * 2 *}$ & $0.63 * * *$ & -0.36 & -0.37 \\
\hline & $(4.49)$ & $(4.34)$ & $(-0.98)$ & $(-0.99)$ \\
\hline \multirow[t]{2}{*}{ Contiguity } & $0.92^{* * * *}$ & $1.00^{* * * *}$ & $0.8 I^{\text {**ak }}$ & $0.84 * * *$ \\
\hline & $(6.79)$ & (7.30) & $(3.46)$ & (3.63) \\
\hline \multirow[t]{2}{*}{ Common language } & $0.72^{* * * *}$ & $0.70^{* * * *}$ & $0.94 * * * *$ & $0.91^{* * * *}$ \\
\hline & $(10.20)$ & $(9.71)$ & (7.74) & $(7.48)$ \\
\hline \multirow[t]{2}{*}{ Aircraft departures } & & 0.01 & & $-0.10 * * *$ \\
\hline & & $(0.44)$ & & $(-3.00)$ \\
\hline \multirow[t]{2}{*}{ Cell phone density } & & 0.02 & & $0.12 * * *$ \\
\hline & & $(1.07)$ & & $(3.10)$ \\
\hline \multirow[t]{2}{*}{ Road length per unit of population } & & $0.08 * * *$ & & $0.16^{* * * *}$ \\
\hline & & $(2.75)$ & & $(4.42)$ \\
\hline \multirow[t]{2}{*}{ Share of paved roads } & & $0.17 * * *$ & & 0.07 \\
\hline & & $(4.37)$ & & $(1.15)$ \\
\hline \multirow[t]{2}{*}{ African exporter } & $-0.35 * * *$ & -0.09 & $-0.27 * *$ & 0.02 \\
\hline & $(-5.08)$ & $(-1.15)$ & $(-2.29)$ & $(0.20)$ \\
\hline Number of observations & 6,208 & 6,208 & 3,086 & 3,086 \\
\hline$R^{2}$ & 0.73 & 0.74 & 0.67 & 0.68 \\
\hline
\end{tabular}




\section{References}

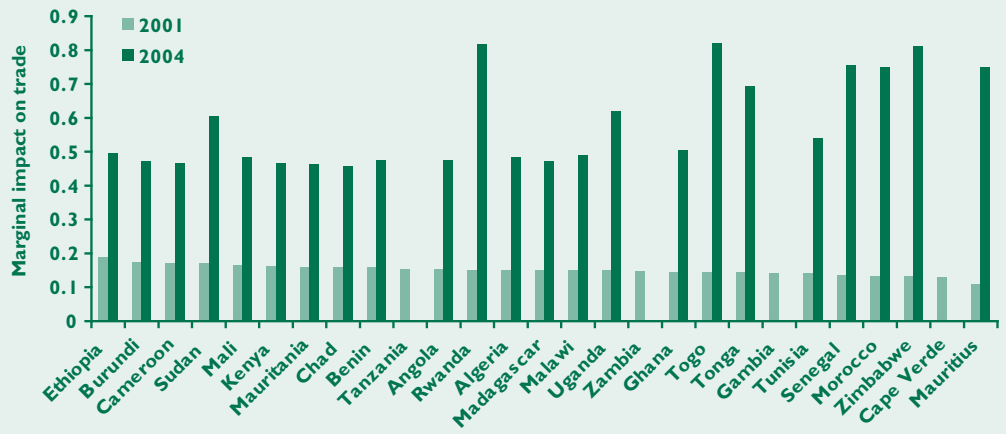

Source: Gravity model projections, 2007.

\section{Figure 3 -Infrastructural complementarities, 200I}

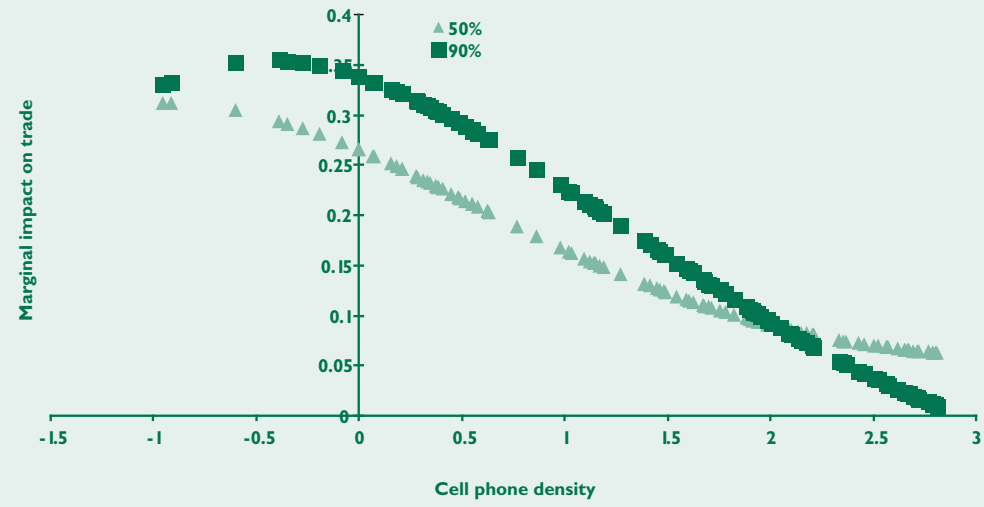

Source: Gravity model projections, 2007.

Note: "50 percent" and "90 percent" indicate that all countries have a road density equal to the highest 50 and 90 percent of the sample, respectively.

Saswati Bora (s.bora@cgiar.org), Antoine Bouët (a.bouet@cgiar.org), and Devesh Roy (d.roy@cgiar.org) are senior research assistant, senior research fellow, and research fellow, respectively, in IFPRI's Markets, Trade, and Institutions Division.
Berisha-Krasniqi, V., A. Bouët, S. Mevel, and D. Roy. 2007. Trade preferences and market access: Evaluating the impact of granting more to African countries. Washington D.C., International Food Policy Research Institute. Computer file.

Bouët, A., Y. Decreux, L. Fontagné, S. Jean, and D. Laborde. 2007. A consistent measure of applied protection. Review of International Economics, forthcoming.

Coe, D. T., and A. W. Hoffmaister. 1998. North-South trade: Is Africa unusual? IMF Working Paper. Washington, D.C.: International Monetary Fund.

Easterly, W. 2006. Planners versus searchers in foreign aid. Asian Development Review 23 (2). Asian Development Bank. <http://www.nyu.edu/fas/institute/dri/Easterly/ File/Planners_vs_Searchers_ADB.pdf>. Accessed 2006.

Evenett, S. 2005. From "trade versus aid" to "aid for trade." WTO News. <http://www.siaw.unisg.ch/org/ siaw/web.nsf/SysWebRessources/wton13epdf/\$FILE/ wtonews13e.pdf $>$. Accessed September 2005.

Foroutan, F., and L. Pritchett. 1993. Intra-Sub-Saharan trade: Is it too little? Journal of African Economies 2 (1): 74-105.

IATP (Institute for Agriculture and Trade Policy). 2006. Can aid fix trade: Assessing the WTO's aid for trade agenda. Minneapolis: IATP.

Rodrik, D. 1998. Trade policy and economic performance in Sub-Saharan Africa. Working Paper 6562. Cambridge, Mass.: National Bureau of Economic Research.

Sachs, J. D., and A. M. Warner. 1997. Sources of slow growth in African economies. Journal of African Economies 6 (3): 335-376.

Subramanian, A., and N. Tamirisa. 2001. Africa's trade revisited. IMF Working Paper. Washington, D.C.: International Monetary Fund.

World Bank. 2000. Can Africa claim the 21st century? Washington, D.C. 2006. World development indicators. Washington, D.C. CD-ROM.

\section{Financial Contributors and Partners}

IFPRI's research, capacity strengthening, and communications work is made possible by its financial contributors and partners. IFPRI gratefully acknowledges the generous unrestricted funding from Australia, Canada, China, Denmark, Finland, France, Germany, India, Ireland, Italy, Japan, Netherlands, Norway, Philippines, Sweden, Switzerland, United Kingdom, United States, and World Bank.

Printed on alternative-fiber paper manufactured from agriculturally sustainable resources that are processed chlorine-free (PCF).

Copyright (c) 2007 International Food Policy Research Institute. All rights reserved. Sections of this document may be reproduced without the permission of but with acknowledgment to IFPRI. Contact ifpri-copyright@cgiar.org for permission to reprint. 